\title{
WestVirginiaUniversity
}

THE RESEARCH REPOSITORY @ WVU

Graduate Theses, Dissertations, and Problem Reports

2003

\section{Identity formation of adolescents involved in selected structured activities}

Sara A. Drake

West Virginia University

Follow this and additional works at: https://researchrepository.wvu.edu/etd

\section{Recommended Citation}

Drake, Sara A., "Identity formation of adolescents involved in selected structured activities" (2003).

Graduate Theses, Dissertations, and Problem Reports. 1773.

https://researchrepository.wvu.edu/etd/1773

This Thesis is protected by copyright and/or related rights. It has been brought to you by the The Research Repository @ WVU with permission from the rights-holder(s). You are free to use this Thesis in any way that is permitted by the copyright and related rights legislation that applies to your use. For other uses you must obtain permission from the rights-holder(s) directly, unless additional rights are indicated by a Creative Commons license in the record and/ or on the work itself. This Thesis has been accepted for inclusion in WVU Graduate Theses, Dissertations, and Problem Reports collection by an authorized administrator of The Research Repository @ WVU. For more information, please contact researchrepository@mail.wvu.edu. 


\title{
IDENTITY FORMATION OF ADOLESCENTS INVOLVED IN SELECTED STRUCTURED ACTIVITIES
}

\section{By}

Sara A. Drake

\author{
A THESIS \\ Submitted to \\ The Davis College of Agriculture, Forestry, and Consumer Sciences \\ at West Virginia University \\ in partial fulfillment of the requirements for the degree of \\ Master of Science \\ in \\ Child Development \\ Department of Family and Consumer Sciences \\ Morgantown, West Virginia \\ 2003 \\ Committee Chair: Carol Markstrom, Ph. D. \\ Wanda Franz, Ph. D. \\ Barbara Warash, Ed. D.
}

Keywords: Identity Formation, Extracurricular Activities, 4-H, Volunteerism Copyright 2003 Sara A. Drake 
Abstract

\section{IDENTITY FORMATION OF ADOLESCENTS INVOLVED IN SELECTED STRUCTURED ACTIVITIES}

Sara A. Drake

Identity formation is seen as the primary developmental task during adolescence according to Erikson (1968). Adolescents' involvement in structured activities such as extracurricular activity, 4-H, and volunteerism were examined to determine their associations with identity formation. Researcher James Marcia (1966) developed four statuses of identity formation: diffusion, foreclosure, moratorium, and achieved. Categorization in one of the four statuses depends upon the levels of both crisis and commitment. Adolescents who are in the identity-diffused category have had no crisis or made no commitment. Those who foreclose, have made a commitment, but have had no crisis. Moratorium is a state of exploration, where a crisis is present, but no commitment has yet been made. Finally, in the identity-achieved state, the individual has faced a crisis and made a commitment (Marcia, 1966).

Participants were grouped into one of four mutually exclusive categories of participation. Participation in each structured individual activity was also examined. It was predicted that those involved in any activity would less likely be classified with a diffused identity status. Also, those involved in any activity would more likely be classified in one of the exploratory statuses, moratorium or achieved.

Five hundred and six students in grades 10 and 11 completed measures of participation and identity formation. Sample data for this study were obtained from a larger study, which examined the effects of a 4-H program, Charting, on adolescent development. Participants were tested in group settings either in local high schools or county Extension Service offices. Participants completed a self-report booklet questionnaire, which included information regarding background information, involvement in activities (extracurricular, 4-H, and volunteerism), a measure of identity, and a measure of fidelity. Based on results from Chi-square tests between 
selected individual activities and the four identity statuses, those not involved in any activity were more likely to be classified as identity diffused and less likely to be classified in identity achievement. Moratorium and achievement were more frequent among those who participated in student government. Achievement was more frequent among those who participated in a service club, and moratorium was more frequent among those in music.

Based on a multiple regression analysis with forward selection, SES of parents, gender of participant, and scores on both identity diffusion and fidelity were found to be significant in regard to prediction of the number of individual structured activities engaged in. Those individuals who had parents from a higher SES were more likely to be involved in structured activities. Presumably, those individuals have more opportunities afforded to them because of the SES of their parents.

Four mutually exclusive categories were delineated and assessed in a MANCOVA with the four identity subscales and a measure of the ego strength of fidelity. The four groupings of activities served as the independent variables. The four identity statuses as well as the measure of fidelity were the dependent variables. SES served as a covariate. The MANCOVA was significant for diffusion, moratorium, and fidelity. Those not involved in any activities scored higher in identity diffusion and moratorium and scored lower in the ego strength of fidelity. Those not participating in any activity were apparently not inclined to making commitments since this is the common trait of diffusion and moratorium. As well, this finding was consistent with non-activity group's lower score on fidelity (highly indicative of commitment). Hence, it appears that it was the commitment component of identity that was most susceptible to involvement in structured activities. 
This area of research is important for the development of youth relative to identity formation. Involvement in any activity is what was found to be important, as opposed to not being in any activity. Those individuals who were not involved in any activity were those who were lacking in terms of identity formation, specifically, they were classified as diffused or foreclosed in their identity status. These individuals are the ones that should be provided with ample opportunities for exploration to support the development of a positive identity status, and encouraged to participate in any activity. 


\section{Table of Contents}

Abstract

ii

Table of Contents

V

List of Figures

vi

List of Tables

Chapter I

Introduction

Chapter II

Review of Literature 3

Identity 3

Extracurricular Activity $\quad 7$

4-H

Volunteerism 12

Hypotheses 16

Chapter III

Methodology

Sample

Procedures

Instruments

Activities

Identity

Fidelity

Chapter IV

20

Results

$\begin{array}{ll}\text { Chapter V } & 31\end{array}$

Discussion $\quad 31$

Limitations of the Study $\quad 34$

Recommendations for Future Research 35

Practical Implications $\quad 35$

References $\quad 38$

$\begin{array}{ll}\text { Appendices } & 42\end{array}$

Appendix A: Demographic Information $\quad 42$

Appendix B: Participation/Activities Measure 44

Appendix C: Extended Objective Measure of Ego-Identity Status (EOMEIS) 47

Appendix D: Fidelity Subscale of the Psychosocial Inventory of Ego Strengths (PIES) 51 


\section{List of Figures}

Fig. 1 - Participation in Music and Identity Statuses $\quad 21$

Fig. 2 - Participation in Student Government and Identity Statuses 23

Fig. 3 - Participation in Issues Group and Identity Statuses 23

Fig. 4 - Participation in Service Club and Identity Statuses 24

Fig. 5 - Participation in Volunteerism and Identity Statuses $\quad 24$

Fig. 6 - Four Types of Participation and Identity Statuses $\quad 25$

Fig. 7 - MANCOVA (Diffusion and Four Types of Participation) 28

Fig. 8-MANCOVA (Moratorium and Four Types of Participation) 30

Fig. 9 - MANCOVA (Fidelity and Four Types of Participation) 30

\section{List of Tables}

Table 1 - Results of Chi-square Tests Between Structured Activities and Identity Statuses 22

Table 2 - Total Activities $\quad 26$

Table 3 - Summary of Regressions for the Total Number of Activities 27

Table 4 - MANCOVA for Four Types of Participation and Identity Variables 29 


\section{Chapter One}

\section{Introduction}

Forming an identity is important. Helping adolescents discover their identity is just as important. To aid this process, activities that are beneficial to identity formation must be identified. Extracurricular activity, 4-H involvement, and volunteerism were examined to determine their relations with identity formation of adolescents. Participation in such activities may have beneficial effects by allowing individuals the opportunities to foster development (Hansen, Larson, \& Dworkin 2003). When compared with those who did not participate in any activity, those who participated were found to have higher school achievement based on grade point averages, more positive attitudes toward school, and higher educational goals (Jacobs \& Chase, 1989). According to Hansen et al. (2003), adolescents who are involved in activities outside of academic settings or recreational, free time with friends, often reflect on experiences in which they are involved. This reflection leads the way to more experiences causing to exploration of one's identity (Hansen et al., 2003).

Developing an identity, or a healthy sense of self, is considered one of the major developmental tasks of adolescence according to Erik Erikson. Erikson has established a model of eight psychosocial stages. At each level, there is a primary developmental task that must be achieved in order to successfully complete that stage. James Marcia has taken Erikson's theory and developed four statuses of identity formation, diffusion, foreclosure, moratorium, and achieved. Adolescents who are in the identity-diffused category have had no crisis or made no commitments. Those who foreclose, have made a commitment, but have had no crisis. Moratorium is a state of exploration, where a crisis is present, but no commitment has yet been 
made. Finally, in the identity-achieved status, the individual has faced a crisis and made a commitment (Marcia, 1966).

Extracurricular activity is any school related activity that occurs outside of regular classes. This type of activity can take many forms ranging from sports to various clubs and organizations. $4-\mathrm{H}$ is a youth development program of the Cooperative Extension Service through a cooperative effort of federal (United States Department of Agriculture), state (land grant universities and colleges), and local resources. Volunteerism is any unpaid service rendered to assist another person, organization, or community. Ultimately, those involved in one or a combination of any of these three areas should have a greater sense of identity.

Previous research has typically examined separate activities regarding identity formation. Most have found involvement in selected activities to be related to a more advanced identity. Very few studies have combined three categories of extracurricular activity, 4-H, and volunteerism. Adolescents can be involved in a multitude of various activities; however, it is difficult to isolate the contributions of each activity on identity formation. The purpose of this research was to expand on this area of research by grouping the selected activities in mutually exclusive categories to determine relations with identity formation. Individual activities, as well as the categories, were examined to determine if previous results could be replicated.

The focus of this thesis was to examine the relations between extracurricular activity, 4$\mathrm{H}$, volunteerism, and adolescent identity formation. Self-report measures were examined among adolescents from non-urban high schools throughout West Virginia. 


\section{Chapter Two}

\section{Review of Literature}

It is difficult for an adolescent to establish her identity. The individual needs a support system and a sense of belonging. She needs to feel good about herself in order to feel secure enough to venture out and explore possibilities on her own. Participation in various activities such as extracurricular, 4- $\mathrm{H}$, and volunteerism may provide the social support one needs to facilitate identity development. Throughout this section, a connection between each activity and identity development is addressed.

\section{Identity}

Erik Erikson is a leading researcher in identity development. Stemming from his work with Freud's psychodynamic theory, he constructed a psychosocial theory yielding eight stages of development, which are sequential, invariant, hierarchical, universal, and genetically determined. This theory links the biological person to the social culture in which he lives. Throughout each of the eight stages, the individual is faced with a crisis that must be overcome to successfully master the stage. A crisis, which leads to potential positive or negative outcomes, is a turning point in development. If the crisis is resolved successfully, an ego strength will emerge. The ego is considered the core of the person, and a rational ego helps the person live an organized life. However if the crisis is not resolved, a weaker ego will develop, which will lead to difficultly in the successful resolution of crises at later stages (Erikson, 1964).

The first psychosocial stage of basic trust versus basic mistrust occurs during the first year of life (Erikson, 1968). Trust is acquired as needs are met in a loving manner. An emotional bond transpires between child and caregiver. This stage yields the ego strength of 
hope, which is fundamental to all future stages. Autonomy versus shame and doubt is the second stage, which occurs between the ages of one and three (Erikson, 1968). Parents foster autonomy by allowing children to perform certain tasks. Will is the ego strength that emerges from positive resolution of this stage. As the child progresses, he enters the stage of initiative versus guilt between the ages of four to five years. The child is testing limits and boundaries, and parents need to encourage, praise, and respond to their child. The ego strength of purpose is the result. Between the ages of six to eleven, the fourth stage of industry versus inferiority is occurring (Erikson, 1968). Industry develops through responsibility, involvement, and completion of tasks. Competence is the ego strength.

The first four stages will aid the adolescent's quest for resolving the stage of identity versus identity (or role) confusion. To successfully resolve the crisis of identity, the individual must begin to acquire skills and knowledge concerning himself, his environment, and his interaction with the environment. He must examine his interests, abilities, roles, and values (Erikson, 1968). This stage is considered a pivotal stage in the life span because during this phase, choices are made that affect later adult life. During a state of psychosocial moratorium, the individual is able to think about future plans, but does not have to commit to any decisions. By the end of this stage, the individual should have a sense of his identity (Erikson, 1968). If this stage is not successfully resolved, the negative outcome is role confusion or negative identity. The individual with the negative resolution does not know who he is or where he is going. The ego strength that emerges from this stage is fidelity, or the ability to commit, and be loyal, to ideas.

If an adolescent successfully navigates herself through the identity crisis, she is believed to have achieved her identity. She has explored options concerning her beliefs, future plans, and 
many other areas affecting her daily life. However, if one does not manage to effectively resolve the crisis, the negative outcome of the stage, identity or role confusion, occurs. In this instance, the youth is incapable of fulfilling roles and expectations placed on her by society as a whole.

The stages of Erikson's theory are hierarchical in nature, meaning that later stages build upon previous stages. Therefore the crisis of identity formation must be successfully resolved before the individual is able to succeed in the stage of intimacy versus isolation, which occurs between the ages of twenty to twenty-four. One must know who he is before he can enter into meaningful relationship with another. Intimacy can only occur after the formation of an individual's identity because intimacy leads to a loss of individual identity (Erikson, 1968). The ego strength that emerges is that of love or a personal commitment to another person. The seventh stage, which spans the ages of twenty-five to sixty-four, is generativity versus stagnation (Erikson, 1968). This stage is concerned with being a contributive member to society, such as through procreation. Care, being widely committed to others beyond your family and friends, is the ego strength that emerges. The final stage is ego-integrity versus despair where one positively reflects on one's life (Erikson, 1968). Wisdom is the ego strength to emerge.

The majority of Erikson's writing revolved around the fifth stage of identity versus identity (or role) confusion. Identity is the defining element of the individual. Many later decisions are affected through the events that occur between the ages of twelve to twenty. Erikson stressed in his theory that the adolescent needs a period of time in order to explore himself and the world around him (Erikson, 1968). This period has been designated as a moratorium. An adolescent needs a time to explore options concerning himself, his future, and his environment. In other words, he needs a time to test the waters to determine his actual versus perceived abilities. The individual is capable of more meaningful relationships, which are used 
as a springboard to test ideas and values. The individual is conducting much experimentation to determine his boundaries and limitations. The individual is able to take on numerous roles and is given unlimited avenues of exploration through interactions with his environment. Acts, which could be considered deviant or delinquent, normally, may be quite natural (Erikson, 1968). They are merely a component of the time of exploration known as "moratorium."

For an individual to resolve the stage of identity versus identity confusion, there must be conflict. Throughout the multiple explorations during the moratorium phase, an individual is struggling with a sense of crisis or multiple crises (Adams \& Montemayor, 1983). The crisis is a crucial element, and the way the individual attempts to deal with the crisis is important.

Researcher James Marcia (1966) expanded upon Erikson's conceptualizations and has identified four statuses of identity formation-identity diffusion, identity foreclosure, identity moratorium, and identity achieved — based upon the level of crisis and commitment. In identity diffusion, an individual has made no commitment, nor has motivation to explore. She has not experienced any crisis. If an individual has not experienced a crisis, but has prematurely committed, then she is said to foreclose. She has made the decision, or commitment, before she was ready. An individual in this status looks more mature because she appears to have everything in order. However, she has made premature judgments and not participated in any exploration. The individual in the state of identity moratorium is in the middle of the identity crisis and is actively exploring options, but has made no commitments. Finally, in identity achieved individuals, a crisis and commitment have occurred. The individual is ready to move onto the next stage of intimacy versus isolation. 


\section{Extracurricular Activity}

Various activities can be classified as extracurricular activities. Any school related activity that an individual participates in outside of her regular classes would be considered as extracurricular. Team sports and school sponsored clubs and organizations are two examples of extracurricular activities. Athletics is a prevalent activity and was found to be the most popular activity in studies conducted by Jacobs and Chase (1989) and Hansen, Larson, and Dworkin (2003).

Studies have been conducted concerning the type and amount of involvement in extracurricular activities. Eccles and Barber (1999) placed extracurricular activities into five categories: (a) prosocial activities, which include volunteerism, (b) performance activities, (c) team sports, (d) school involvement, which include school sponsored organizations, and (e) academic clubs. Research has found that extracurricular activity yield positive outcomes through participation. An individual gains a sense of belonging. It is also associated with positive academic outcomes. Eccles and Barber (1999) reported that involvement in certain activities could be protective and prevent some types of negative behaviors. For example, participation has been linked to higher academic performance (Eccles \& Barber, 1999). However, it has also been shown that participating in certain extracurricular activities, mainly team sports, can lead to negative behavior such as experimentation with alcohol (Eccles \& Barber, 1999; Hansen et al., 2003). The amount of involvement can be defined by the quantity of activities participated in, level of participation as to whether the individual is an officer or a member, and the frequency of participation in practices/meetings.

Certain activities can be seen as protective activities. Protective activities are those that facilitate and enhance social and learning environments for individuals who are considered at 
risk, or do not have access to the quality environments that are considered positive and stimulating (Larson, 1994). These activities serve as positive experiences for those involved and promote preferential actions. They aid in encouraging positive psychological integration. Larson (1994) stated that, "In addition to facilitating adolescents' social integration, extracurricular activities have often been credited with facilitating their personal development and well-being" (p. 56). These activities are successful in this respect because an individual is allowed to experiment with different roles. The adolescent has an opportunity to master concepts and interact with others. (Larson, 1994)

Being involved in extracurricular activities can also be viewed as protective in regard to dropping out of high school. In a study conducted by McNeal (1995), the protective aspect of extracurricular activities, mainly athletics, was supported. Those who participated in athletics were less likely to drop out of high school. Mahoney (2000) also reported this finding in a longitudinal study of at-risk youth in regard to participation in extracurricular activities. It was believed that involvement in such activities heightened individual interests and strengths through social relationships (Mahoney, 2000). The benefits of involvement were shown to continue even after graduation from high school.

Various domains can influence the formation of one's identity (Erikson, 1968). Kleiber and Kirshnit (1991) believed that extracurricular activity is one such domain that impacts identity formation, and discussed the effects of sport involvement on identity formation. It is believed that being actively involved in extracurricular activity aids the identity formation process by allowing the individual to develop skills, or competencies, necessary for success (Kleiber \& Kirshnit, 1991). Through participation in these activities, the individual is interacting with others, gaining recognition from others, experiencing a context for achievement, gaining 
skills, and learning about social rules and norms (Kleiber \& Kirshnit, 1991). The independence that one experiences through participation in extracurricular activity is an important aspect of successful identity formation.

There appear to be gender differences in the effects of extracurricular activities on identity formation. McCabe, Roberts, and Morris (1991) researched the effects of athletic activity and body image on identity. The relationship was relatively simple for males resulting in a linear path from involvement to identity formation. The male gender is considered to be independent and individualistic. Kleiber and Kirshnit (1991) found that male participation was based on achievement and competition. The benefits for participation, including improvements in self-image and self-concept and high levels of life satisfaction, were found to be much greater for males (McCabe et al., 1991). McCabe et al. (1991) reported that a positive identity is formed through participation and success of boys in the arena of athletics. For females, who are more social and nurturing by nature, it was reported that the effects were less obvious, but still present. Kleiber and Kirshnit (1991) found that female participation in sports was based on friendship. Participation led to external rewards, freedom, independence, and increased interaction with peers (McCabe et al., 1991).

\section{$4-H$}

Youth-serving organizations exist in every community. Examples of such organizations include boys/girls club, 4-H, scouting, and church youth groups. Goals of such programs usually relate to positive youth development (Eccles \& Gootman, 2002). By participating in such organizations, an individual should gain knowledge and skills, which enable her to develop the necessary abilities to adapt and survive in society. As stated by Eccles and Gootman (2002), 
"participation in voluntary structured activities during non-school time is associated with development of positive identity, increased initiative, and positive relationships with diverse peers and adults" (p. 30).

Each individual has different perspectives and gains information and skills from an organization. This is due in part to what the individual brings with her to the organization, such as attitudes, previous skills, and level of participation. However, the quality of the organization also has an effect (Sarver, Johnson, \& Verma, 2000; Thomas \& Ladewig, 1987). Those organizations that are viewed to be of higher quality are those that enable the adolescent to explore, experiment, and develop new skills and thoughts. As reported by Sarver et al. (2000) "A worthy youth organization as perceived by high school students satisfies adolescent development needs and encourages leadership, community service, enthusiasm, morality, dignity of work, mature relationships. .." (p. 5).

The community program of interest in this study is $4-\mathrm{H}$, which is the youth component of the Cooperative Extension Service. Cooperative Extension Service (CES) is exactly what its name implies. It is cooperative in the fact that it has federal (United States Department of Agriculture), state (land grant colleges/universities), and local (county extension agents) components. These components work to serve communities by dissipating or extending knowledge for the benefit of clientele. Youth development is one aspect of the CES and is partly achieved through the institution of the 4-H program. The motto of 4-H is "To make the best better." Extension agents and volunteer leaders try to make this happen in every individual that is a part of the program.

Common positive characteristics of involvement cited from those involved with the 4-H program include leadership development, a sense of belonging, and confidence. National 4-H 
goals include helping youth acquire positive self-concepts, social skills, and leadership skills, explore future career opportunities, and help facilitate positive attitudes (Weatherford \& Weatherford, 1987). 4-H has a "Learning by Doing" philosophy, where the organization allows for training and practice of various skills. This helps the individual explore various options and develop new skills (Thomas \& Ladewig, 1987)

In a study conducted by Thomas and Ladewig (1987), personal development and attitudes relative to youth programs were addressed. Each area of youth programs was assessed by three categories of adults, those who participated in 4-H, those who participated in other non4-H youth organizations, and those that did not participate Of the nine areas concerning personal development that were addressed, it was determined that cooperation and responsibility ranked the highest as the largest contribution to personal development of both groups who had participated in some activity (Thomas \& Ladewig, 1987). It was also discovered that 4-H alumni consistently ranked each area of personal development higher than the rankings of the other two groups. Both groups that participated in youth organizations strongly agreed that their participation aided them in their adult endeavors because of the enhancement of knowledge and skills that were achieved.

Astroth and Haynes (2002) delivered a questionnaire to approximately 2500 Montana youth. The questionnaire encompassed eight domains including positive self-identity, leadership, social competency, and self-confidence. The authors reported that involvement in any activity was seen as protective because the individuals who participated were less likely to be involved in deviant behaviors (Astroth \& Haynes, 2002). It was also reported that 4-H participants had advantages in numerous areas over peers who were involved in other activities and those not involved in any activity. Astroth and Haynes (2002) specifically stated that those 
in "4-H have a positive self-identity" (p. 8). Other areas of difference included success in school based on letter grades, involvement as leaders, and being perceived as a role model (Astroth \& Haynes, 2002).

In a study conducted by Hansen et al. (2003), individuals involved in community organizations, such as 4-H, reported similar results when compared to individuals who participated in service activities. It was discovered that those involved in community organizations were challenged in the areas of future planning, leadership skills, and altruism (Hansen et al., 2003). A theme that was discovered was the ability of the organizations to provide the individual with socialization into adult roles (Hansen et al., 2003). This ability provided the individual with the type of exploratory period needed at this age to facilitate identity formation.

There is a likelihood of 4-H members to be involved and active in other organizations (Astroth \& Haynes, 2002; Youniss, McLellan, \& Yates, 1997). Based on the tendency of an adolescent to be involved in various activities, it is sometimes difficult to separate the effects of solely one organization. Care must be taken to determine the effects of one activity or organization over another. Members involved in 4-H consistently volunteer time back to the community in which they live in order to strengthen it. Funding from Congress specifically has supported this community development aspect (Ladewig \& Thomas, 1987).

\section{Volunteerism}

Many programs survive and function as a result of the assistance from volunteers. Volunteers freely give of their time and talents to support various causes. Volunteerism has been defined by Knauft (1992) as "any activity that is carried out to help others and not conducted for 
monetary or material gains" (p. 12). Positive attributes of volunteering include a sense of accomplishment and a sense of helping others. Volunteering at a young age, or in other words, during adolescence, has been shown to foster later volunteerism and later participation in the community (Hamilton, \& Fenzel, 1987; Knauft, 1992). Through volunteering, one comprehends the value of community involvement and is encouraged to continue this valuable service throughout her life (Johnson, Beebe, Mortimer \& Snider, 1998). Many youth are participating in volunteerism. According to Knauft (1992), approximately three-fifths of adolescents are volunteering.

There may be a wide array of reasons that individuals volunteer. They may still be egocentric in their views and are using these opportunities to gain recognition or admittance into college. Some may just have an altruistic nature (Knauft, 1992). Clary, Ridge, Stukas, Snyder, Copeland, Haugne, and Miene (1998) proposed six functions of volunteering: (a) values of care and concern, (b) understanding or gaining new knowledge, (c) socialization by being with one's friends, (d) career enhancement, (e) protective in nature by reducing guilt feelings, and (f) enhancement of personal development. Recently, there has been a shift in legislation promoting youth volunteerism and service (Youniss \& Yates, 1997). Volunteering, or prosocial activities, has been proven beneficial, as stated by Johnson et al. (1998), "volunteering encourages selfexploration with respect to values, job interests, and one's role in the community" (p. 326). Therefore, if the reason for undertaking such acts is discovered, then perhaps more individuals could be motivated to volunteer. Studies have been conducted to determine motivations of volunteers because of this. Clary, Snyder, and Stukas (1996) discovered that individuals have many reasons for volunteerism, including personal satisfaction and a need to help the community. 
Youniss, McLellan, Yang, and Yates (1999) conducted a study to examine the impact of community service on identity formation and development. It was hypothesized that participation would foster the development of an identity through further knowledge of society and adult roles (Yates \& Youniss, 1996; Youniss et al., 1999). Daily activities of the students sampled were grouped into five categories: school, sports, fun, performing arts, and solitary. Community service was also addressed on the questionnaire. It was expected that those involved in community service would have a greater sense of self and would be actively involved in other organizations (Youniss et al., 1999). This study discovered that most daily activities were positively related to community service.

Those individuals who participate in service activities benefit in many ways. Youniss, McLellan, and Yates (1999) asserted that through volunteer service, an opportunity exists for identity development. By giving of her time to help someone in need, the individual has an opportunity to discover new responsibilities concerning her life and society. Hansen et al. (2003) discovered that youth reported higher rates for many areas when compared to individuals involved in academic, performance, and sport activities. These areas included personal development, identity reflection, emotional regulation, and leadership development. By participating in volunteerism, one is given the opportunity to reflect on her experience (Yates \& Youniss, 1996). Hamilton and Fenzel (1987) conducted a study of 4-H youth volunteers in New York and discovered that participation had "positive effects on adolescents" pro-social attitudes, upon their developing sense of themselves, and upon the knowledge and skills they exercise in their voluntary activities" (p. 20). Involvement in community service aids in the youth's development of life skills. Life skills facilitate later success and include: positive self-concept, 
positive outlook for the future, goal setting skills, reflection, responsibility, and positive academic outcomes (McLaughlin, 2000).

By participating in community service, an individual gains knowledge and skills. The participation offers the youth opportunities for a link between the self and society. As one is able to help others, she is also free to explore and reflect on her own capabilities. Youniss and Yates (1997) asserted, "in working to help other persons in need, adolescents can begin to experience their own agency" (p.3). Through this opportunity, the individual is given a great opportunity to explore her identity and her role in society. The experience gained is vastly different between participants, but allows the individual a sense of accomplishment. Through the experience of helping others, the individual has, to a certain degree, taken on the responsibility of caring for society (Youniss \& Yates, 1997). She is directly affecting the life of someone else, whether that affect is immediately identified or only identified after a reflection of the experience. In a study conducted by Newmann and Rutter (1983) of students in high school volunteer programs, it was discovered that the program elevated the student's sense of personal competence, which led to only a small impact on the development of social skills. Even though they were minor, the effects were beneficial to the student.

Volunteerism can occur strictly on its own without any involvement of the volunteer in any other organization. However, this is usually not the case, an overlap usually exists with community and social organizations (Knauft, 1992; Yates \& Youniss, 1996). The more activities the individual was involved in, the greater the likelihood she would participate in some type of volunteer service (Nolin et al, 1997). Various organizations such as charities, churches, and youth organizations such as Boy Scouts, Girl Scouts, and 4-H, encourage and mediate volunteerism (Yates \& Youniss, 1996; Youniss \& Yates, 1997). Civic duty and helping others 
are stressed in both youth-serving organizations of 4-H and scouts (Sarver, Johnson, \& Verma, 2000).

\section{Hypotheses}

The areas of extracurricular activity, 4-H, and volunteerism may overlap with individual participation in any combination of the three activities. However, each domain should enhance the formation of a positive identity in rural youth. The purpose of this research was to determine the relationship between extracurricular activity, 4-H involvement, volunteerism, and identity formation in rural Appalachian adolescents.

\section{Hypothesis 1}

Individual activities were assessed according to their relations with identity. These activities included: music, drama, sports, student government, yearbook club, service club, hobby club, vocational club, issues group, volunteerism, and 4-H. The scores received on the measure of identity were categorical in nature. Those involved in any activity were predicted to be classified with a diffused identity status. Also, those involved in any activity were predicted to be more likely to be classified in one of the exploratory statuses, moratorium or achieved.

\section{Hypothesis 2}

Participants were grouped into four mutually exclusive categories: (a) 4-H and any other activity, (b) extracurricular activity only, (c) extracurricular activity and volunteerism, and (d) no activity. Participants' scores on the continuous measures of both Identity and Fidelity were assessed. The comparison groups were exploratory in nature and were used to try to ascertain the right combination of activity. Each activity grouping was predicted to show greater exploration and more likely to be classified as less diffused and more achieved in identity status. 


\section{Chapter Three}

\section{Methodology}

The sample data for this study were obtained from a larger study, which examined the effects of a 4-H program, Charting, on adolescent development. This study was conducted by Dr. Carol Markstrom and Dr. Patty Mulkeen of West Virginia University.

\section{Sample}

Participants were surveyed from non-urban counties in West Virginia. Participants were predominately from the White racial background. The total sample included 506 participants, which consisted of 205 male and 301 female adolescents of ages $15(n=164), 16(n=238)$, and 17 $(n=104)$ in $10^{\text {th }}$ to $11^{\text {th }}$ grades. Socioeconomic status (SES) was determined through self-report information from the participant regarding parental education levels. Categories could be selected ranging from " $1=$ completed high school" to " $9=$ earned professional degree $(\mathrm{Ph} . \mathrm{D} ., \mathrm{M}$. D., etc)."

\section{Procedures}

Participants were tested in group settings either in high schools or county Extension service offices. A total of 16 high schools and 11 county 4-H Extension offices participated in the study. Letters that described the study were mailed to the parents of potential participants. Parents were asked to sign consent forms and return them in the enclosed self-addressed, stamped envelope.

Research assistants and county Extension agents were trained and then administered questionnaire booklets to those participants: (a) for whom signed parental consent were on file, 
(b) who were present on the day of testing, and (c) who signed assent forms at the time of testing.

\section{Instruments}

Participants from 16 West Virginia high schools completed a booklet questionnaire in group contexts on two occasions with an eight-month gap between the times of testing. The questionnaire included information regarding background information, involvement in activities (extracurricular, 4-H, and volunteer), a measure of identity, and a measure of fidelity.

\section{Activities}

Activities were assessed in three areas: (a) extracurricular, (b) 4-H involvement, and (c) volunteerism. A listing of items was provided to determine the level of participation in various extracurricular activities. Responses could be checked as 1="school/community does not offer," 2="did not participate," 3="participated," and 4="participated as a captain/co-captain." The responses were collapsed into two general categories, participated or did not participate, for purpose of analyses. Specific extracurricular activities that were addressed included: sports (team and individual), creative arts of drama and music, issues group, and student government.

Involvement in 4-H was determined by adding the category of 4-H to a listing of activities. Responses could be checked as 1="school/community does not offer," $2=$ ="did not participate," 3="participated," and 4="participated as a officer/leader." A later section dealt specifically with 4-H activity involvement. Individuals who indicated that they were involved with 4-H were asked to answer more in depth questions. These included the years of membership, positions held, and awards received.

Volunteerism was determined according to a "yes" or "no" response to the question "Do you currently do any volunteer work (without pay)?" Individuals who indicated that they 
volunteered were asked to provide additional information. This included a brief description of the activity and the number of hours per week spent volunteering.

Participants were classified into one of four groups, which were mutually exclusive. Group one consisted of those individuals who participated in 4-H and any other activity $(\mathrm{n}=79)$. Group two consisted of those who were only involved in extracurricular activity ( $\mathrm{n}=223)$. Those individuals who participated in extracurricular and volunteerism $(n=110)$ were categorized as group three. Finally, those that did not participate in any activity $(n=61)$ were classified as group four.

\section{Identity}

The Extended Objective Measure of Ego Identity Status (EOMEIS) consists of 64 selfreport items. The EOMEIS is a common measure used for research on identity formation, and reliability and validity have been reported (Adams, Bennion, \& Huh 1989; Markstrom, Sabino, Turner, \& Berman, 1997). While both interpersonal and ideological forms of identity are assessed on the EOMEIS, a condensed version of 32 self-report items was used in this study to measure ideological identity only. Ideological identity assesses occupation, politics, religion, and a philosophical life style. The respondents answered each item on a six-point Likert scale ranging from 6 "strongly disagree" to 1 "strongly agree." Eight items were summed for each subscale of diffusion, foreclosure, moratorium, and achieved. The measure was scored in a second manner by which each subject was classified into one of the four identity statues.

\section{Fidelity}

As a second measure of the identity crisis, the ego strength of fidelity was assessed. The Psychosocial Inventory of Ego Strengths (PIES) was devised and validated by Markstrom et al. (1997). The measure consists of 64 self-report items to measure the eight ego strengths 
delineated by Erikson (1964). The subscale of fidelity, which is the ego strength to emerge from the stage of identity versus identity confusion, was used. The respondents answered each item on a five-point Likert scale ranging from 5 "describes me very well" to 1 "does not describe me well." Negatively phrased items were reverse scored. Items were summed for each subscale to create a continuous variable.

\section{Chapter Four}

\section{Results}

Individual structured activities, as well as four mutually exclusive groupings were examined to determine if relationships existed between participation in a given activity or grouping of selected activities and an individual's identity status. Chi-square tests and regression analyses were conducted. Cronbach's alphas were assessed for the four identity subscales and the fidelity subscale. All were found to be acceptable at $>.60$. The Cronbach's alphas were 0.63 for diffusion, 0.73 for foreclosure, 0.63 for moratorium, 0.65 for achieved, and 0.62 for fidelity. Participants were then classified into one of the four identity statuses of achieved, moratorium, foreclosure or diffusion based on the results from the Extended Objective Measure of Ego Identity Status (EOMEIS). Crosstabulations were conducted with the individual structured activities $^{1}$ of music $(n=135)$, drama $(n=77)$, sports $(n=258)$, student government $(n=74)$, yearbook club $(n=45)$, service club $(n=108)$, hobby club $(n=84)$, vocational club $(n=62)$, issues group $(n=105)$, volunteerism $(n=168)$, and 4-H $(n=79)$. Based on the results of the Chi-square test between each individual activity and identity status, it was determined that music $\left(X^{2}=10.41, p<.05\right)$, student government $\left(X^{2}=18.05, p<.01\right)$, service club $\left(X^{2}=23.65, p<\right.$

\footnotetext{
${ }^{1} \mathrm{n}$ indicates the sample size for each activity. Participants could be in more than one activity.
} 
$.01)$, issues group $\left(X^{2}=14.68, p<.01\right)$, and volunteerism $\left(X^{2}=8.36, p<.05\right)$ were significant (see Table 1).

Those participants involved in music were more likely to be classified as moratorium and less likely to be classified as diffused (see Figure 1). Moratorium and achievement were more frequent among those participants involved in student government (see Figure 2) and issues group (see Figure 3). Those individuals involved in student government (see Figure 2) and issues group (see Figure 3) were less likely to be classified as diffuse. Participants involved with service club (see Figure 4) and volunteerism (see Figure 5) were more likely classified with an achieved identity status, and less likely classified with a diffused identity status.

\section{Figure 1}

\section{Participation in Music and}

\section{Identity Statuses}

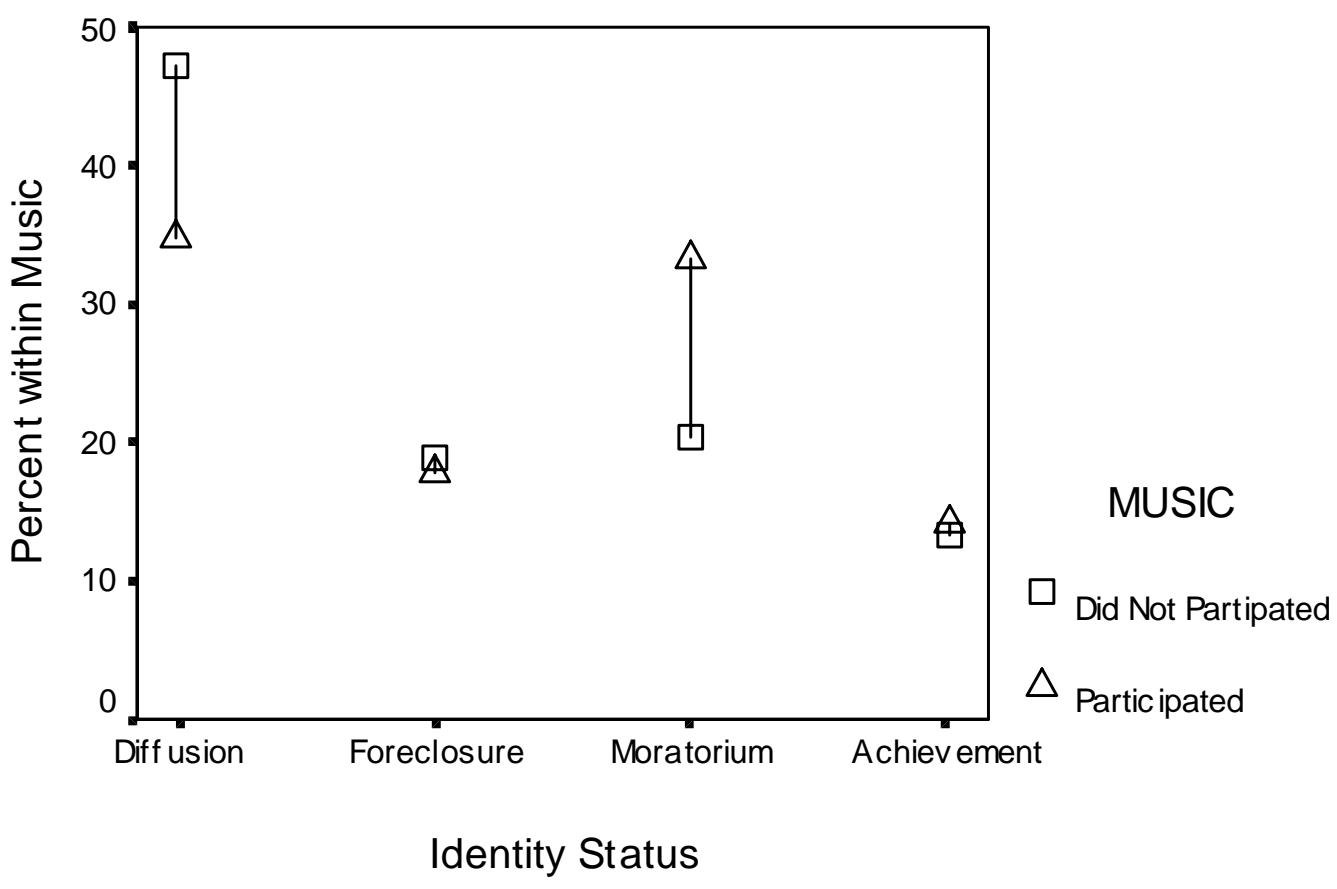




\section{Table 1}

Results of Chi-square Tests Between Structured Activities and Identity Statuses.

Activity

Chi-square value

Music

$10.41 *$

Drama

Sports

4.61

Student Government

18.05**

Yearbook Club

6.60

Service Club

23.65**

Hobby Club

Vocational Club

Issues Group

$14.68 * *$

Volunteerism

8.36*

$4 \mathrm{H}$

Four Types of Participation

17.34*

$* p<.05 . \quad * * p<.01$. 
Figure 2

\section{Participation in Student Government and}

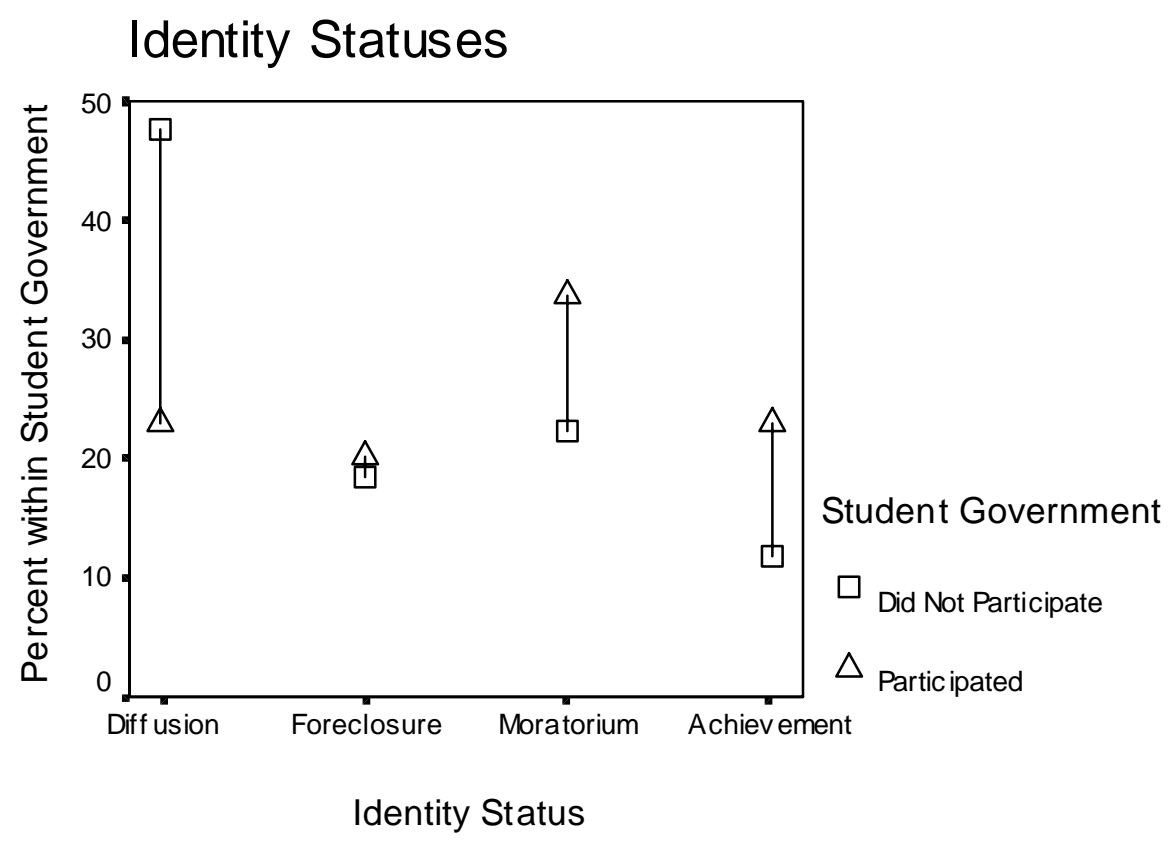

Figure 3

Participation in Issues Group and

Identity Statuses

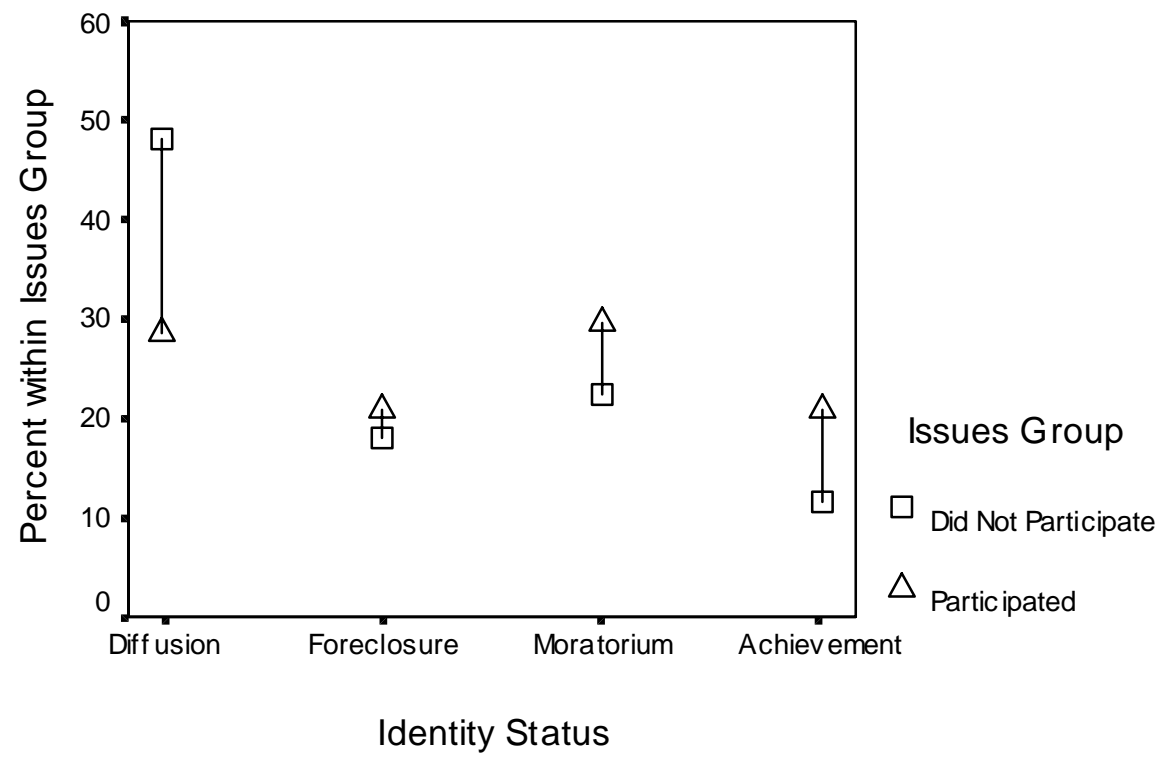


Figure 4

\section{Participation in Service Club and}

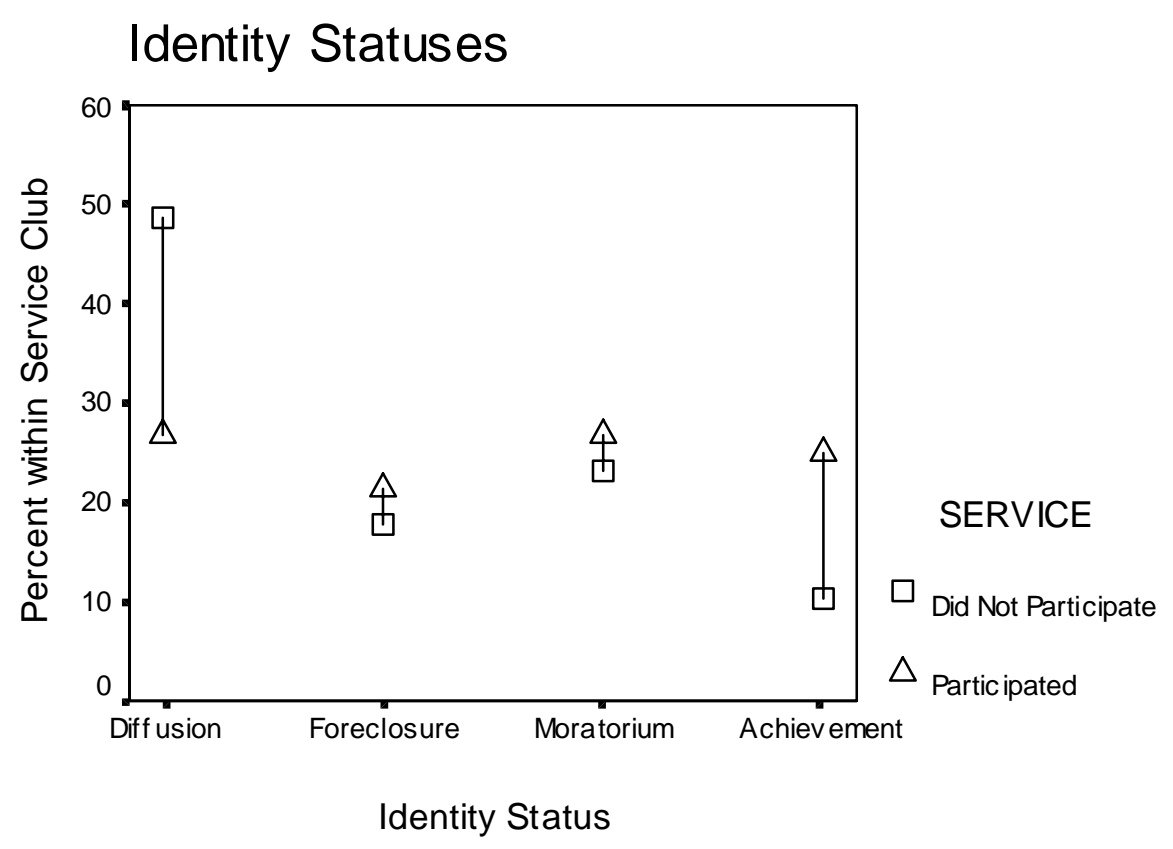

Figure 5

\section{Participation in Volunteerism and}

Identity Statuses

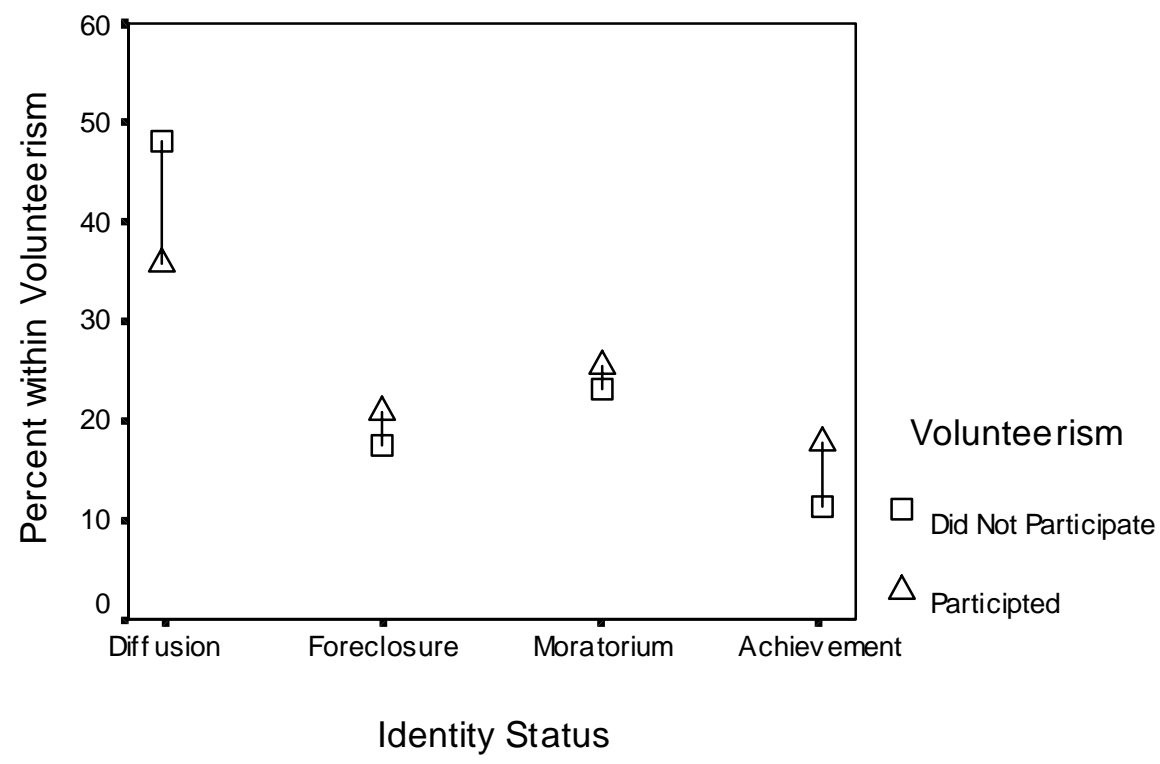


Based on the three categories, four mutually exclusive groupings were formed. Group one contained those individuals involved in 4-H and any other activity $(n=79)$. Group two consisted of those participating in extracurricular activities only $(n=223)$. Those individuals who participated in extracurricular and volunteerism were classified as group three $(n=110)$. Finally, individuals who did not participate in any activity comprised the fourth group $(n=61)$. It was also determined from the chi-square test that the four types of participation were significant $\left(X^{2}=17.34, p<.05\right)$. Those who participated in any activity were more likely to be classified as achieved and less likely to be classified as diffused (see Figure 6). Those individuals, who did not participate in any activity, were more likely to be classified in the diffused identity status (see Figure 6).

\section{Figure 6}

\section{Four Types of Participation and}

\section{Identity Statuses}

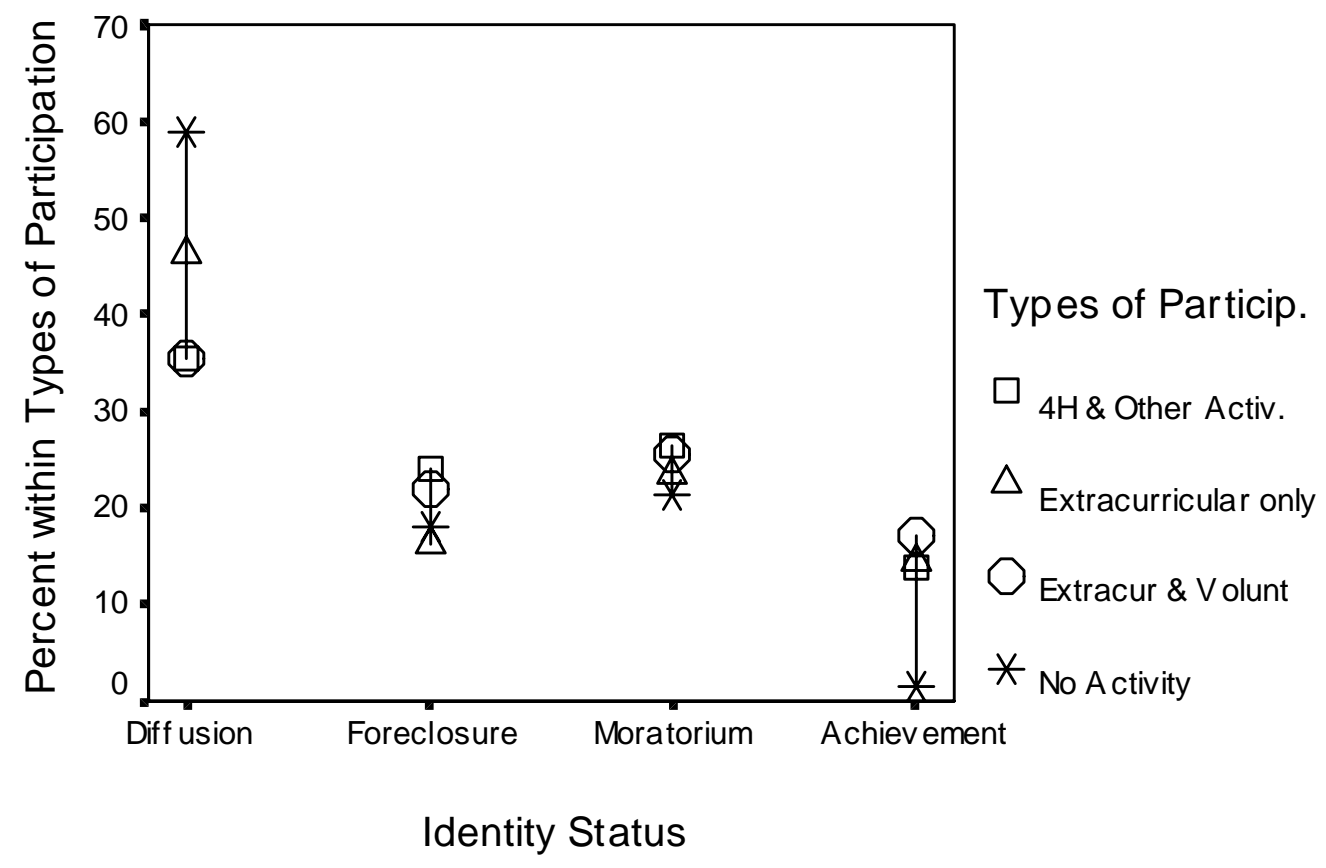


Individual activities were summed to determine the total number of activities that each individual participated in (see Table 2). The total ranged from zero activities to nine activities. Approximately three-fourths of all participants participated in a range of zero to three activities.

TABLE 2

Total Activities.

\begin{tabular}{|l|l|l|l|l|}
\hline \multicolumn{2}{|l|}{} & Frequency & Percent & $\begin{array}{l}\text { Cumulative } \\
\text { Percent }\end{array}$ \\
\hline Valid & 0 & 70 & 13.8 & 13.8 \\
\hline & 1 & 117 & 23.1 & 37.0 \\
\hline & 2 & 102 & 20.2 & 57.1 \\
\hline & 3 & 96 & 19.0 & 76.1 \\
\hline & 4 & 49 & 9.7 & 85.8 \\
\hline & 5 & 39 & 7.7 & 93.5 \\
\hline & 6 & 18 & 3.6 & 97.0 \\
\hline & 7 & 10 & 2.0 & 99.0 \\
\hline & 8 & 3 & .6 & 99.6 \\
\hline & 9 & 2 & .4 & 100.0 \\
\hline & Total & 506 & 100.0 & \\
\hline
\end{tabular}

A stepwise regression analysis with forward selection was conducted based on the total number of activities of all participants. The predictor variables included socioeconomic status (SES), gender of participant, scores on four identity subscales, and scores on the measure of fidelity. These variables predicted the level of participation in individual structured activities, which was measured by the total number of activities in which an individual participated. SES of parents, gender of participant, and scores on both identity diffusion and fidelity were found to be significant in regard to prediction of participation in individual structured activities. SES was found to be the greatest predictor of involvement in structured activities with a $R^{2}$ value of 0.098 at a significance of $p<0.01$. The score on the diffusion subscale of the measure of identity statuses was the next best predictor of involvement. The $\mathrm{R}^{2}$ value for diffusion was 0.150 with a significance level of $p<0.01$. Following the top two predictors, the gender of the participant 
was also useful in predicting an individual's involvement in a given activity with a $\mathrm{R}^{2}$ value of 0.167 at $p<0.05$. Finally, scores on the fidelity measure, with a $\mathrm{R}^{2}$ value $=0.175, p<0.05$ was also a significant predictor of involvement (see Table 3). Therefore, total $\mathrm{R}^{2}$ for the four significant variables was 0.175 . The value of $\mathrm{sr}^{2}$ is obtained when the partial correlation value is squared. The value of $\mathrm{sr}^{2}$ represents the unique contribution from each independent variable to the prediction of the dependent variable.

\section{TABLE 3}

Summary of Regressions for the Total Number of Activities.

\begin{tabular}{lcccccc}
\hline Variable & $\mathrm{B}$ & $\mathrm{SE} \mathrm{B}$ & $\mathrm{B}$ & $\mathrm{sr}^{2}$ & $\mathrm{t}$ value & $\mathrm{R}^{2}$ \\
Step 1: ${ }^{\mathrm{a}} \mathrm{SES}$ & .288 & .043 & .282 & .0858 & $6.772^{* *}$ & 0.098 \\
Step 2: ${ }^{\mathrm{b}}$ Identity Diffusion & .00529 & .013 & -.179 & .0320 & $-4.025^{* *}$ & 0.150 \\
Step 3: ${ }^{\mathrm{c}}$ Gender & .411 & .160 & .110 & .0135 & $2.577^{*}$ & 0.167 \\
Step 4: ${ }^{\mathrm{d}}$ Fidelity & .00387 & .018 & .097 & .0090 & $2.118^{*}$ & 0.175 \\
\hline${ }^{\mathrm{a}} \mathrm{R}^{2}=.10 \mathrm{p}<.000 .{ }^{\mathrm{b}} \Delta \mathrm{R}^{2}=.05 \mathrm{p}<.000 .{ }^{\mathrm{c}} \Delta \mathrm{R}^{2}=.02 \mathrm{p}<.002 .{ }^{\mathrm{d}} \Delta \mathrm{R}^{2}=.01 \mathrm{p}<.035$. \\
${ }^{*} \mathrm{p}<.05 .{ }^{*}<.01$.
\end{tabular}

Regarding the four mutually exclusive groupings of activities, MANCOVA analyses were conducted to measure the continuous assessments of identity with each group X gender configuration. The four groupings of activities served as the independent variables. The four identity statuses of achieved, moratorium, foreclosed, and diffused, as well as the measure of fidelity were the dependent variables. Each dependent variable was treated as continuous in nature. SES was controlled and served as a covariate. Wilks' Lambdas were significant at the 0.05 level for gender and the four types of participation. No significant gender X participation interactions were found. The dependent variables of diffusion (see Figure 7), moratorium (see Figure 8), and fidelity (see Figure 9) were found to be significant between those not involved in any activity versus those that were involved. Those that did not participate in any activity scored significantly higher than the three activity groupings in identity diffusion and moratorium, and 
lower on fidelity (see Table 4). There were no significant interactions between the participation groupings regarding any identity status or the ego strength of fidelity. There was no difference between groups one (4-H and any other activity), two (extracurricular activity only), and three (extracurricular activity and volunteerism) in regard to identity diffusion, identity moratorium, and fidelity. For groups one, two, and three, the mean levels were 26.26, 26.60, and 25.19 respectively regarding identity diffusion, $27.31,27.60$, and 26.95 for identity moratorium, and $30.16,30.21$, and 31.18 for the measure of fidelity (see Table 4).

\section{Figure 7}

MANCOVA

Diffusion and Four Types of Participation

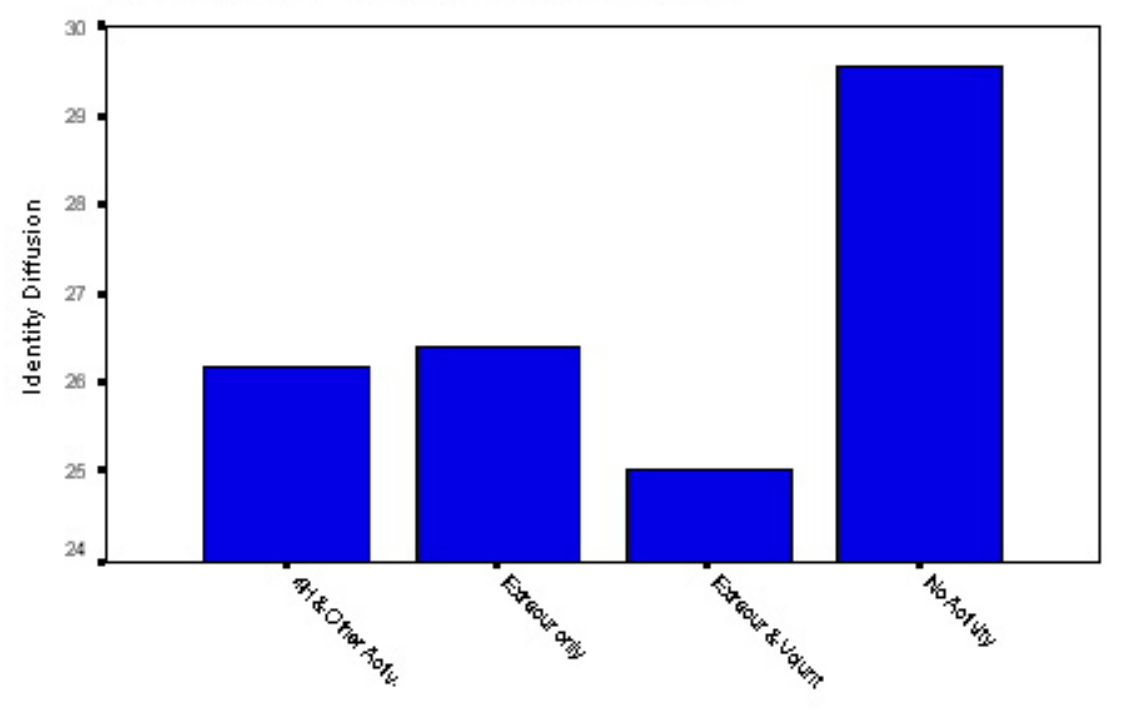

Four Types of Participation 


\section{Table 4}

MANCOVA for Four Types of Participation and Identity Variables (Controlling for Parental SES).

\begin{tabular}{|c|c|c|c|c|c|c|}
\hline & & $\begin{array}{c}\text { 4-H \& Any } \\
\text { Other Activity } \\
\quad(n=79)\end{array}$ & $\begin{array}{c}\text { Extracurricular } \\
\text { Only } \\
(\mathrm{n}=223)\end{array}$ & $\begin{array}{l}\text { Extracurricular } \\
\text { \& Volunteerism } \\
\quad(n=110)\end{array}$ & $\begin{array}{l}\text { No Activity } \\
\quad(n=61)\end{array}$ & $\begin{array}{l}\text { F-Value } \\
(3,470)\end{array}$ \\
\hline \multirow[t]{2}{*}{ Diffusion } & Adj. M & 26.26 & 26.60 & 25.19 & 29.39 & $6.320^{*}$ \\
\hline & $\mathrm{SE}$ & .737 & .407 & .581 & .766 & \\
\hline \multirow[t]{2}{*}{ Foreclosure } & Adj. $M$ & 24.04 & 23.35 & 23.10 & 24.58 & .831 \\
\hline & $\mathrm{SE}$ & .824 & .456 & .650 & .857 & \\
\hline \multirow[t]{2}{*}{ Moratorium } & Adj. M & 27.31 & 27.60 & 26.95 & 30.09 & $3.938^{*}$ \\
\hline & $\mathrm{SE}$ & .728 & .402 & .574 & .757 & \\
\hline \multirow[t]{2}{*}{ Achievement } & Adj. M & 33.53 & 33.43 & 34.29 & 32.88 & .902 \\
\hline & $\mathrm{SE}$ & .697 & .385 & .549 & .725 & \\
\hline \multirow[t]{2}{*}{ Fidelity } & Adj. M & 30.16 & 30.21 & 31.18 & 28.70 & $4.187^{*}$ \\
\hline & $\mathrm{SE}$ & .535 & .296 & .421 & .556 & \\
\hline
\end{tabular}

Note: Multivariate test: Wilks’ Lambda $\mathrm{F}=1.757, p<.05$.

$* p<.01$. 


\section{Figure 8}

MANCOVA

Moratorium and Four Types of Participation

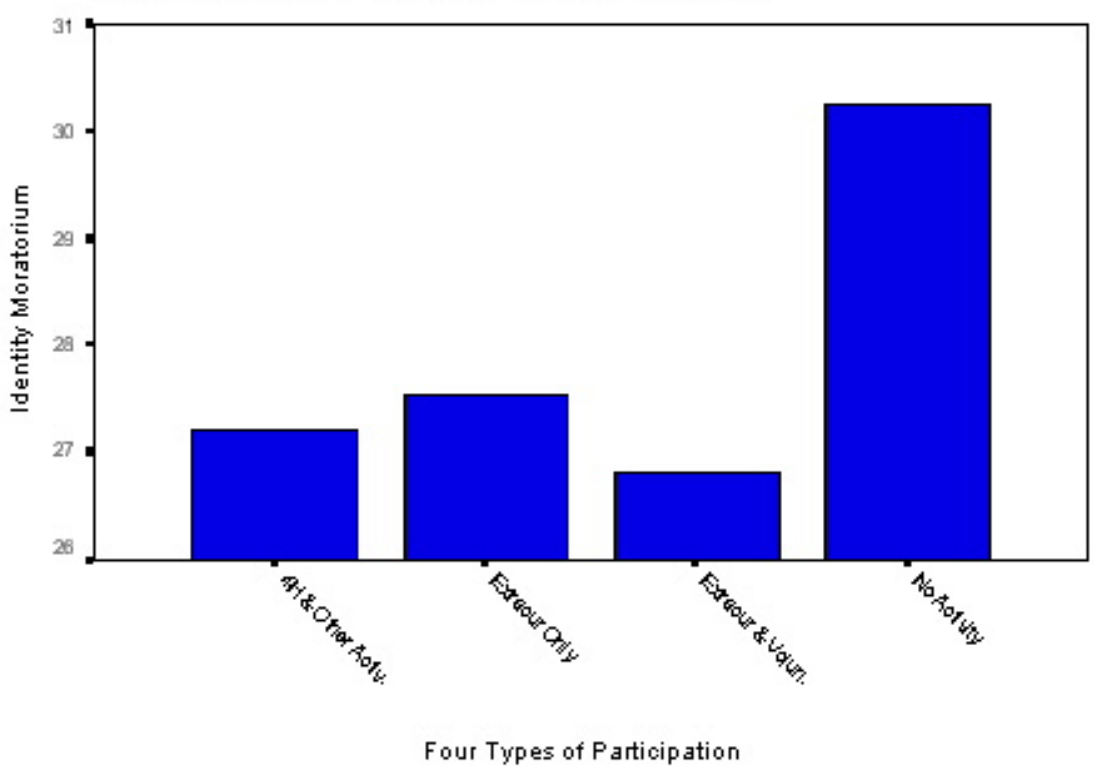

Figure 9

MANCOVA

Fidelity and Four Types of Participation

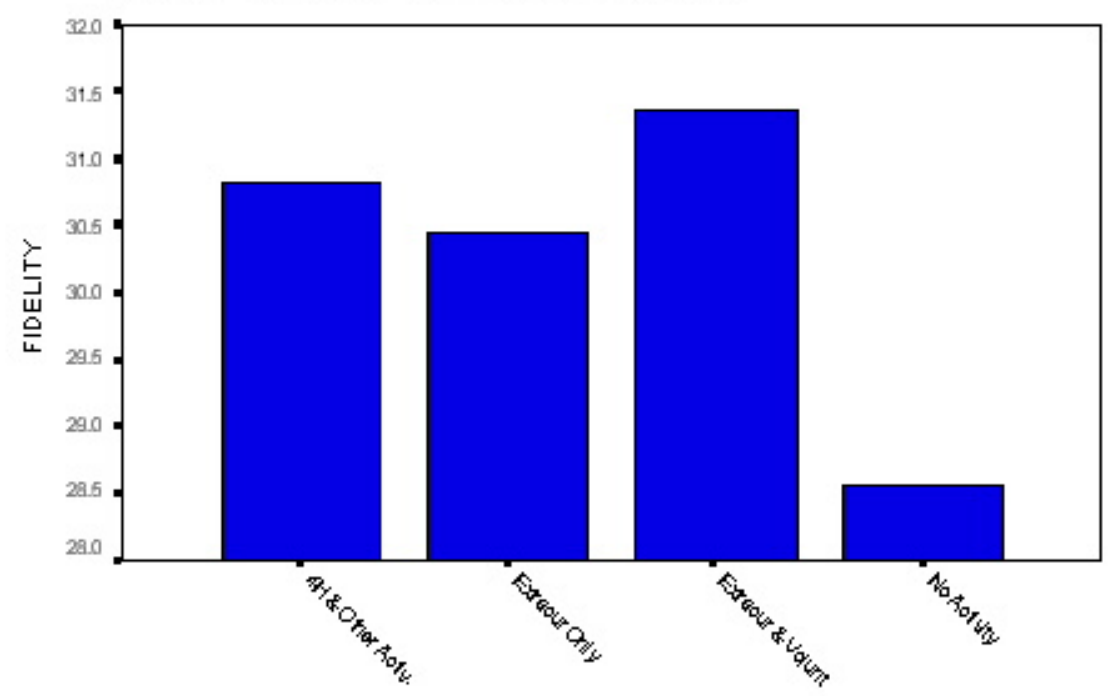

Four Types of Participation 


\section{Chapter Five}

\section{Discussion}

Individual activities were examined with the four identity statuses according to crosstabulations and Chi-square tests. Certain individual activities and the four groupings were significantly related to the identity status of the participant. Involvement in music, student government, issues group, service club, volunteerism, as well as the four types of participation were significant when compared to the identity statuses. When examined individually, drama, sports, yearbook club, hobby club, vocational club, and 4-H were not found to be significant. These activities are mainly self-fulfilling activities. The goals of these activities focus on selfdevelopment. Adolescents are egocentric in their views, which must be challenged during this time, and adolescents must be encouraged to view situations from perspectives other than their

own. Based on the results from this study, it appears that when an individual is challenged and encouraged to move away from an egocentric line of thought, a higher level of identity formation is achieved.

Those individuals who participated in music were less likely to be classified in diffusion and more likely to be classified in moratorium. Music is a very exploratory, creative activity. Perhaps the creative nature of music is congruent with the exploration activities associated with moratorium. There were a higher percentage of those participating in student government and issues groups in the moratorium and achieved statuses. Student government provides hands-on exposure to decision-making processes and commitments. The exploration and level of commitment that is faced with participation in this activity could aid in the higher rate of achieved individuals. Through participation in an issues group, individuals are encouraged to discuss current issues. This awareness leads to an exploration of events and issues that an 
individual may not normally experience. Therefore, this activity leads to more participants being classified in the statuses of moratorium and achieved.

Service club participants and those who volunteered were less likely to be classified as diffused, and more likely classified as achieved. Service clubs and volunteerism are similar in nature, that is, individuals are helping other people or organizations. Such a prosocial activity allows individuals to discover aspects about themselves (Johnson et al., 1998), reflect on their experiences (Yates \& Youniss, 1996), and make commitments to other people (Youniss \& Yates, 1997).

It was stated in hypothesis one that participation in any activity would yield higher scores in one of the exploratory statuses of moratorium or achieved. Not all activities were shown to be significant. Of the significant activities, it was shown that the participants were more likely classified with an identity status of moratorium and/or achieved and less likely to be classified with a diffused identity.

When mutually exclusive categories were derived and comparisons were made, it was determined that those individuals who did not participate in any activity were more likely to be classified as diffused, which supports the first part of hypothesis two. If an individual is not involved, there is limited opportunity for exploration or commitment. A common theme to all of the significant cross-tabulations was the higher proportion of identity diffused in the noninvolvement categories. Lack of involvement in activities perhaps curtails influence from important social sources that can provide meaning and opportunities for exploration and commitment.

Certain individual activities were found not to be significant, namely, drama, sports, yearbook club, hobby club, vocational club, and 4-H. Merely indicating membership in the 
above activities did not necessarily mean that the individual took full advantage of the services that the organization offered. Regarding sports, it has been shown in previous studies that participation in athletics can lead to negative behaviors, which may offset the positive values that were examined (Eccles \& Barber, 1999; Hansen et al., 2003). Perhaps these activities are beneficial but in ways not addressed in this study.

The total number of activities served as the dependent variables in the regression analysis. The dependent variables were continuous in nature. Being involved in a greater number of activities would lead to higher score on the fidelity subscale, which in turn would translate into a higher level of commitment. Thus, those individuals involved in numerous activities, have a higher level of commitment.

Based on a stepwise regression analysis, SES of parents, gender of participant, and scores on both identity diffusion and fidelity were found to be the strongest predictors in regard to the prediction of participation in a number of structured activities. SES of parents was found to be the strongest predictor of involvement in activities. Those individuals who had parents from a higher SES were more likely to be involved in a greater number of structured activities. The youth from these families likely have more opportunities afforded to them because of the SES status of their parents. Those individuals from families with a low SES may not be able to participate in activities because of an after-school job. They may also be needed at home to perform certain family responsibilities such as babysitting.

A second approach in this study was to classify participants into four mutually exclusive categories of participation, and then examine these groups according to the continuous subscales of identity and fidelity. While there was variation between the four groups, the three groups that participated in some combination of activity were similar based on results from the MANCOVA. 
Those not involved in any activity scored higher on the identity statuses of diffusion and moratorium, and lower on the measure of fidelity. It was expected that the no activity group would score higher on the diffusion subscale. It was also expected that each activity grouping would score higher on the achieved subscale. However, there was no significant difference between any of the groups regarding scores on the achieved subscale.

Those not participating in any activity were apparently not inclined to making commitments since this is the common trait of diffusion and moratorium. As well, this finding is consistent with the non-activity group's lower score on fidelity (highly indicative of commitment). Hence, it appeared from the MANCOVA that it was the commitment component of identity that was most susceptible relative to involvement in structured activities.

\section{Limitations of the Study}

It was difficult to separate and isolate unique activity variables. In a time where so many individuals are involved in multiple activities, it is hard to assess which activity is responsible for the desired outcome. For example, the effects of 4-H on adolescent identity formation could not be directly ascertained. When this variable was isolated, there was only one individual who participated solely in 4-H. Therefore, the four mutually exclusive groupings of activities were derived.

Another limitation included the level of participation. Indicating membership in a club or organization does not imply active participation. There was no defining variable in regard to level of participation. One can be lead to believe that when an individual indicated participation as a captain or officer, there was more active involvement. Again, this may not be the case and this was not analyzed in regard to the outcome of this study. 


\section{Recommendations for Future Research}

In future research, it would be important to have large sample sizes in order to isolate impacts from individual activities controlling for involvement in all other kinds of activities. Interactions with gender should be considered. Based on regression analyses from this study, gender was found to be significant. SES should continue to be included (either as a covariate as in the case of this study or as an independent variable) because this research has shown that those of lower SES are less likely to be involved in structured activities.

When examining the individual activities, it was discovered that the type of activity an individual participates is important. Adolescents are in transition from an egocentric stage. Those who participate in activities, which help to refocus thinking from the egocentric view, were significant in regard to being classified in one of the exploratory statuses of identity. Those who participate, gain skills relevant to identity formation. The involved individual is being challenged and is allowed to explore new possibilities. Self-involved activities in which an individual participates, such as sports, drama, and hobby club, do not aid in shifting an adolescents egocentric view. These self-fulfilling activities were not shown to aid identity formation.

\section{Practical Implications}

This area of research is important for the development of youth relative to identity formation. It is also important for teachers, administrators, counselors, coaches, and anyone working with youth to understand that the type of involvement does matter. An adolescent's way of thinking must be challenged. The individual must be encouraged to think about others and to view situations from other points of view. 
Those individuals who are not involved in any activity are those who are lacking in terms of identity formation. First, those who are not involved are not given an outlet to explore. Exploration is one of the key factors in establishing one's identity. Without opportunity to explore, one is left with what is viewed as few choices. An individual would then be classified as having either a diffused or foreclosed identity.

An individual who is in the identity-diffused category has had no crisis or made no commitments. The individual is faced with no crisis or reason to explore any options that are present in her life. Based on the results of this study, these are the individuals who are not participating in any activity. These are individuals that may be from a lower SES family. The options for the individual from a lower SES family are limited from the beginning. If he is not participating in any activity to help him explore possibilities, then he is just extending the gap between his diffused status and one of the positive statuses of moratorium or achieved.

A foreclosed identity is classified by an individual making a commitment, but without facing a crisis. Without a crisis, there is no exploration. A commitment is made without any regard to other options. An example of a foreclosed individual is one who chooses to go to the same college his parents went to without even considering or applying to any other school. A foreclosed individual is limiting her options. She is not exploring opportunities to enhance her competence in any area. She is merely allowing others to decide what is best for her.

Identity formation is considered a pivotal stage. The choices that are made during this period of one's life will affect the future. If an individual does not successfully resolve the stage of identity versus identity (or role) confusion, the youth is perceived to be incapable of fulfilling roles and expectations placed on her by society. The crisis of identity formation must be successfully resolved before progressing to the next stage of intimacy. Therefore, those 
individuals who are determined to be in the diffused or foreclosed status should receive extra encouragement, understanding, and support. They should also be provided with ample opportunities for exploration to support the development of a positive identity status. 


\section{References}

Adams, G. R., Bennion, L. \& Huh, K. (1989). Objective measure of ego identity status: A reference manual. ( $2^{\text {nd }}$ ed.). Guelph, Ontario: Author.

Adams, G. R. \& Montemayor, R. (1983). Identity formation during early adolescence. Journal of Early Adolescence, 3(3):193-202.

Astroth, K. A. \& Haynes, G. W. (2002). More than cows and cooking: Newest research shows impact of 4-H. Journal of Extension, 40(4). Retrieved from March 25, 2003 from http://www.joe.org/joe/2002august/a6.shtml.

Clary, E. G., Ridge, R. D., Stukas, A. A., Snyder, M., Copeland, J., Haugen, J., \& Miene, P. (1998). Understanding and assessing the motivations of volunteers: A functional approach. Journal of Personality and Social Psychology, 74(6):1516-1530.

Clary, E. G., Snyder, M., \& Stukas, A. A. (1996). Volunteers' motivations: Findings from a national survey. Nonprofit and Voluntary Sector Quarterly, 25(4):485-505.

Eccles, J. S. \& Barber, B. L. (1999). Student council, volunteering, basketball, or marching band: What kind of extracurricular involvement matters? Journal of Adolescent Research, 14(1): 10-43.

Eccles, J. \& Gootman, J. (2002). Community programs to promote youth development. Washington, D.C.: National Academy Press.

Erikson, E. (1968). Identity: youth and crisis. New York: Norton.

Hamilton, S. F. \& Fenzel, L. M. (1987). The effect of volunteer experience on early adolescents' social development. American Educational Research Association: Washington, DC. 
Hansen, D. M., Larson, R. W., \& Dworkin, J. B. (2003). What adolescents learn in organized youth activities: A survey of self-reported developmental experiences. Journal of Research on Adolescence, 13(1):25-55.

Jacobs, L. C. \& Chase, C. I. (1989) Student participation in and attitudes toward high school activities: Findings from a national study. North Carolina: The University of North Carolina Press.

Johnson, M. K., Beebe, T., Mortimer, J. T., \& Snyder, M. (1998). Volunteerism in adolescence: A process perspective. Journal of Research on Adolescence, 8(3):309-332.

Kleiber, D. A. \& Kirshnit, C. E. (1991). Sport involvement and identity formation. In L. Diamant (Ed.) Mind-body maturity: Psychological approaches to sports, exercise, and fitness. New York: Hemisphere Publishing Company.

Knauft, E. B. (1992). America’s teenagers as volunteers. Washington, DC: Metropolitan Life Foundation.

Ladewig, J. \& Thomas, J. K. (1987). Assessing the impact of 4-H on former members. College Station: Texas Tech University.

Larson, R. (1994). Youth organizations, hobbies, and sports as developmental contexts. In R. K. Silbereisen \& E. Todt (Eds.), Adolescence in context: The interplay of family, school, peers, and work in adjustment. New York: Springer-Verlag.

Marcia, J. E. (1966). Development and validation of ego-identity status. Journal of Personal and Social Psychology, 3(5):551-558.

Markstrom, C. A., Sabino, V. M., Turner, B. J., \& Berman, R. C. (1997). The Psychosocial Inventory of Ego Strengths: Development and validation of a new Eriksonian measure. Journal of Youth and Adolescence, 26(6): 705-732. 
Mahoney, J. L. (2000). School extracurricular activity participation as a moderator in the development of antisocial patterns. Child Development, 71(2):502-516.

McCabe, A. E., Roberts, B. T., \& Morris, T. E. (1991). Athletic activity, body image, and adolescent identity. In L. Diamant (Ed.) Mind-body maturity: Psychological approaches to sports, exercise, and fitness. New York: Hemisphere Publishing Company.

McLaughlin, M. W. (2000). Community counts: How youth organizations matter for youth development. Washington, DC: Public Education Network.

McNeal, Jr., R. B. (1995). Extracurricular activities and high school dropouts. Sociology of Education, 68(1):62-80.

Newmann, F. M. \& Rutter, R. A. (1983). The effects of high school community service programs on the students' social development. Washington, DC : National Institute of Education.

Nolin, M. J., and others (1997). Student participation in community service activity. Rockville, MD: Westat, Inc.

Sarver, D., Johnson, E., Verma, S. (2000). A tool to assess the worth of a youth organization. Journal of Extension, 38(3):1-6. Retrieved March 10, 2003 from http://www.joe.org/joe/2000june/rb3.html.

Thomas, J. K. \& Ladewig, H. (1987). Adult assessments of social learning experiences during adolescent participation in 4-H and other youth programs. Paper presented at the Annual Meeting of the Southern Rural Sociological Association, Nashville, TN.

Weatherford, D. E. \& Weatherford, C. G. (1987). A review of theory and research found in selected experiential education, life skills development, and 4-H program impacts literature. Raleigh, NC: The North Carolina Agriculture Extension Service. 
Yates, M. \& Youniss, J. (1996). Community service and political-moral identity in adolescents. Journal of Research on Adolescents, 6(3):271-284.

Youniss, J., McLellan, J. A., Yang, S., \& Yates, M. (1999). The role of community service in identity: Normative, unconventional, and deviant orientations. Journal of Adolescent Research, 14(2), 248-261.

Youniss, J., McLellan, J. A., \& Yates, M. (1997). What we know about engendering civic identity. American Behavioral Scientist, 40(5):620-631.

Youniss, J., McLellan, J. A., \& Yates, M. (1999). Religion, community service, and identity in American youth. Journal of Adolescence, 22:243-253.

Youniss, J. \& Yates, M. (1997). Community Service and Social Responsibility in Youth. Chicago, IL: University of Chicago Press. 
APPENDIX A

Demographic Information 
1. Age:

2. Sex: male Birthdate:

3. Current grade in school:

Name of School:

4. What is your average grade in school? (check one):

A

B

C

D

F

5. Ethnic/racial background (if you are more than one race, check all that apply): African American (Black)

American Indian Asian American Latino (Hispanic) White American Other (please identify)

6. What are your parents' (or parent figures') education levels?

Check Appropriate Lines

Completed grade school

Mother Father

Attended some high school Graduated high school

Attended trade/technical school

Graduate trade/technical school

Attended some college

Earned bachelor's degree

Earned master's degree

Earned profession degree

(e.g., Ph.D., M.D., J.D.) 
APPENDIX B

Participation/Activities Measure 


\section{Participation/Activities Measure}

1.) Please mark all that apply for EACH sports activity that you have participated in THIS SCHOOL YEAR.

$\begin{array}{llll}\begin{array}{l}\text { School } \\ \text { does not } \\ \text { have }\end{array} & \begin{array}{l}\text { Did not } \\ \text { participate }\end{array} & \text { Participated } & \begin{array}{l}\text { Participated } \\ \text { in as a Captain/ } \\ \text { Co-Captain }\end{array}\end{array}$

TEAM SPORTS:

(baseball, basketball, football, soccer, swim team, hockey, volleyball and etc.)

\section{INDIVIDUAL SPORTS:}

(Cross country, gymnastics, golf, tennis, track, wrestling, etc.)

\section{OTHERS:}

(cheerleading, pom-pom, drill team, etc.)

2.) Please mark one for each activity that you have participated in THIS SCHOOL YEAR.

\section{Clubs or Groups:}

$\begin{array}{ll}\text { School/ } & \text { Did not } \\ \text { Community } & \text { participate }\end{array}$

Participated does not offer

\section{participate}

Participated as an officer/

Leader

a. Band, orchestra, chorus, choir, or other musical group

b. 4-H

c. Student government

d. NHS or other academic honor society

e. School yearbook, newspaper, etc.

f. Service clubs (AFS, Key club) g. Hobby clubs

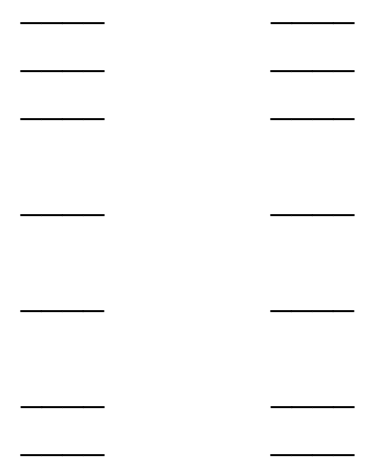




\begin{tabular}{|c|c|c|}
\hline $\begin{array}{l}\text { School/ } \\
\text { Community } \\
\text { does not offer }\end{array}$ & $\begin{array}{l}\text { Did not } \\
\text { participate }\end{array}$ & Participated \\
\hline
\end{tabular}

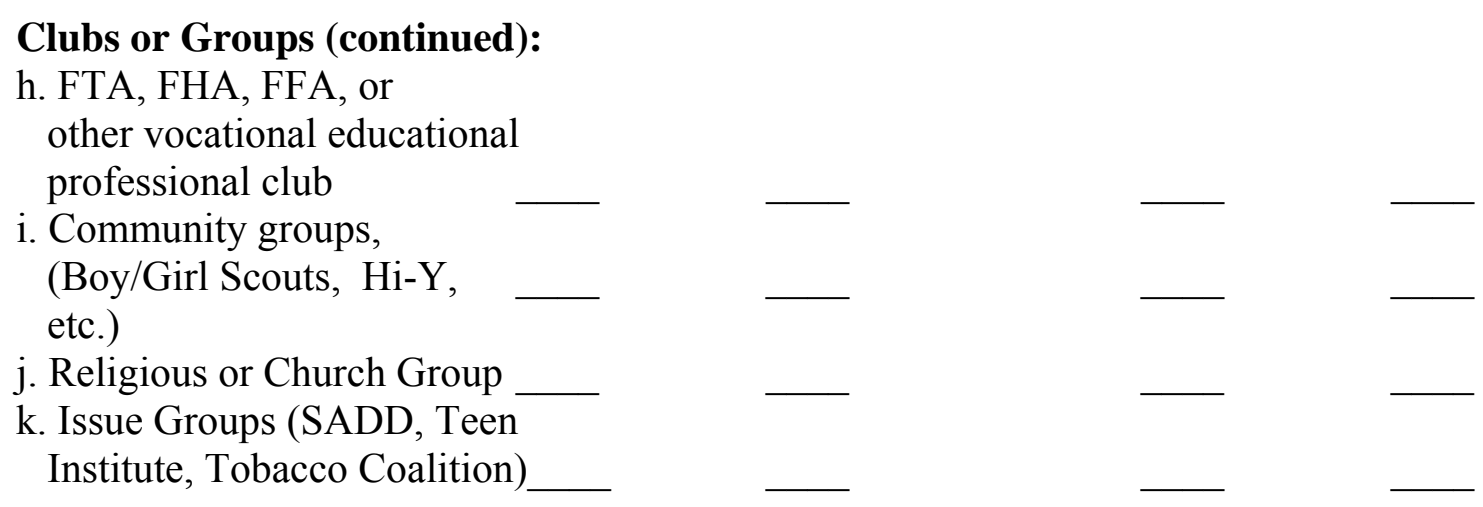

3.) Do you currently do any volunteer work (without pay)? __ Yes _ _ No

\section{4-H Activity Involvement}

1. How long have you been in $4-\mathrm{H}$ ? years

2. Please circle any positions you have held in 4-H. Circle all that apply.

$\begin{array}{ll}\text { President } & \text { Vice-President } \\ \text { Treasurer } & \text { Secretary } \\ \text { News Reporter } & \text { Parliamentarian } \\ \text { Historian } & \text { Chief of Tribe } \\ \text { Sagamore of Tribe } & \end{array}$

3. Please circle any awards you have received through 4-H. Circle all that apply.

$\begin{array}{ll}\text { Head } & \text { Heart } \\ \text { Hands } & \text { Health } \\ \text { Spirit of Camp } & \text { Scholarship to a Camp }\end{array}$


APPENDIX C

Extended Objective Measure of Ego-Identity Status (EOMEIS) 
Directions: Read each item and indicate to what degree it reflects your own thoughts and feelings. If a statement has more than one part, please indicate your reaction to the statement as a whole. On the line next to each item, write the letter that indicates your answer.

$$
\begin{aligned}
& A=\text { strongly agree } \\
& B=\text { moderately agree } \\
& C=\text { agree } \\
& D=\text { disagree } \\
& E=\text { moderately disagree } \\
& F=\text { strongly disagree }
\end{aligned}
$$

1. I haven't chosen the occupation I really want to get into, and I'm just working at whatever is available until something better comes along.

2. When it comes to religion I just haven't found anything that appeals and I don't really feel the need to look.

3. There's no single "life style" which appeals to me more than another.

4. Politics is something that I can never be too sure about because things change so fast. But I do think it's important to know what I can politically stand for and believe in.

5. I'm still trying to decide how capable I am as a person and what jobs will be right for me.

6. I don't give religion much thought and it doesn't bother me one way or the other.

7. I'm looking for an acceptable perspective for my own "life style" view, but I haven't really found it yet.

8. I haven't really considered politics. It just doesn't excite me much.

9. I might have thought about a lot of different jobs, but there's never really been any question since my parents said what they wanted.

10. A person's faith is unique to each individual. I've considered and reconsidered it myself and know what I can believe.

11. After considerable thought I've developed my own individual viewpoint of what is for me an ideal "life style" and don't believe anyone will be likely to change my perspective. 


$$
\begin{aligned}
& \text { EOM-EIS - Self-Perception (cont.) } \\
& \qquad \begin{aligned}
\mathrm{A} & =\text { strongly agree } \\
\mathrm{B} & =\text { moderately agree } \\
\mathrm{C} & =\text { agree } \\
\mathrm{D} & =\text { disagree } \\
\mathrm{E} & =\text { moderately disagree } \\
\mathrm{F} & =\text { strongly disagree }
\end{aligned}
\end{aligned}
$$

12. I guess I'm pretty much like my folks when it comes to politics. I follow what they do in terms of voting and such.

13. I'm really not interested in finding the right job, any job will do. I just seem to flow with what is available.

14. I'm not sure what religion means to me. I'd like to make up my mind but I'm not done looking yet.

15. My own views on a desirable life style were taught to me by my parents and I don't see any need to question what they taught me.

16. There are so many different political parties and ideals. I can't decide which to follow until I figure it all out.

17. It took me a while to figure it out, but now I really know what I want for a career.

18. Religion is confusing to me right now. I keep changing my views on what is right and wrong for me.

19. In finding an acceptable viewpoint to life itself, I find myself engaging in a lot of discussions with others and some self exploration.

20. I've thought my political beliefs through and realize I can agree with some and not other aspects of what my parents believe.

21. My parents decided a long time ago what I should go into for employment and I'm following through with their plans.

22. I've gone through a period of serious questions about faith and can now say I understand what I believe in as an individual.

23. My parents' views on life are good enough for me, I don't need anything else.

24. I'm not sure about my political beliefs, but I'm trying to figure out what I can truly believe in. 


$$
\begin{aligned}
& \text { EOM-EIS - Self-Perception (cont.) } \\
& \qquad \begin{aligned}
\mathrm{A} & =\text { strongly agree } \\
\mathrm{B} & =\text { moderately agree } \\
\mathrm{C} & =\text { agree } \\
\mathrm{D} & =\text { disagree } \\
\mathrm{E} & =\text { moderately disagree } \\
\mathrm{F} & =\text { strongly disagree }
\end{aligned}
\end{aligned}
$$

25. It took me a long time to decide but now I know for sure what direction to move in for a career.

26. I attend the same church as my family has always attended. I've never really questioned why.

27. I guess I just kind of enjoy life in general, and I don't see myself living by any particular viewpoint to life.

28. I really have never been involved in politics enough to have made a firm stand one way or the other.

29. I just can't decide what to do for an occupation. There are so many that have possibilities.

30. I've never really questioned my religion. If it's right for my parents it must be right for me.

31. After a lot of self-examination I have established a very definite view on what my own life style will be.

32. My folks have always had their own political and moral beliefs about issues like abortion and mercy killing and I've always gone along accepting what they have. 


\section{APPENDIX D}

Fidelity Subscale of the Psychosocial Inventory of Ego Strengths (PIES) 
The Fidelity Subscale of the Psychosocial Inventory of Ego Strengths

Directions:

Read each item carefully and consider the degree to which it describes you.

Write the number signifying your response on the line next to each item.

5

Describes me very well

\section{Theme 1}

20. I don't pretend to be something that I'm not.

37. I believe in being true to myself and others.

10. I find that my opinions are frequently influenced by others.

41. I'm not really sure what I believe in.
2

Does not describe me well

\section{Theme 2}

18. When I make a commitment to something, I stick with it.

53. I stand up for the people and causes that are important to me.

6. I prefer to be free-floating without having to worry about commitments to other people or things.

48. I have trouble accepting a particular purpose or role in life. 